ウズラ大腿骨器官培養の骨髄骨形成に及ぼす性ホルモンの影響

\author{
加藤久美子・杉山稔恵 ・楠原征治* \\ 新潟大学大学院自然科学研究科, 新潟市 950-21 \\ * 新潟大学農学部, 新潟市 $950-21$
}

(1995. 9. 4 受付)

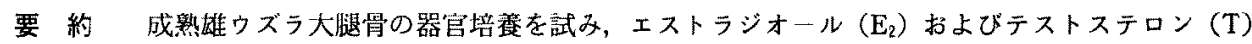
が骨内膜細胞の分化・增殖および骨邻骨形成能に及ぼす影響について検討した。

$\mathrm{E}_{2}$ あるいは $\mathrm{T}$ の単独添加培養液を用いて培盖した場合, 大腿骨骨内膜表面では培養前と比較して, 前 骨芽細胞が多数観察された。ささらに， $E_{2}$ および $\mathrm{T}$ の両方を添加した場合では, 前骨芽細胞がより多く出 現していだ，しかし，牛胎子血清を含まない培養液では，有糸分裂像および骨芽細胞は観察されず，骨

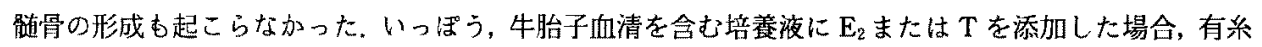
分裂像术上び骨芽細胞か観察され，骨随骨の形成も認められた，とりわけ，牛胎子血清を含む培珡液に $\mathrm{E}_{2}$ および Tを併用添加して培養した場合，骨内膜表面に多くの骨芽細胞が観察され，骨随骨の発達が顕 著であった。
\end{abstract}

日畜会報, $67(1): 64-68,1996$

鳥類䧳の特異組織である骨噵骨は, 産畉期にのみ骨䯣 腔に出現し ${ }^{22}$, 卵款形成のためのカルシゥム眝葴器官之 して重要な役割を果たしている ホルモン，とりわけエストラジオール $\left(\mathbf{E}_{2}\right)$ およびテス トステロン (T) の刺激により誘導されることが示唆さ れている た雄のウズラに $\mathrm{E}_{2}$ を投与すると，投与後 48 時間以内に 骨内膜細胞が前骨芽細胞に移行し，さらに有系分裂を経 て骨芽細胞に分化し，骨髄骨を形成することが知られて いる3.6-8.12,14). しかしながら，去勢したウズラに $E_{2}$ のみ の投与では骨䯣骨の形成が起こらず， $\mathrm{T}$ の存在下で $\mathrm{E}_{2}$ を投与したときにのみ，骨䯣骨が形成されることが知ら れている゙．このことは， $\mathrm{E}_{2}\llcorner\mathrm{~T}$ の両方の作用によって， 骨髅骨の形成が行なわれることを示唆している。

本研究では，成熟した雄ウズラ大腿骨の器官培稂を試 み， $\mathrm{E}_{2}$ おょびTが骨䯣骨における骨形成系細胞の分

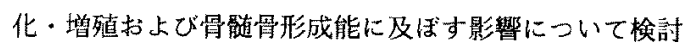
した.

\section{材料および方法}

供試動物として成等した阵のウズラ（3-5 カ月龄，100 一 $120 \mathrm{~g}$ ）を使用した。これらのウズラは㸡血瘖殺した

日畜会報, 67 (1)：64-68
後, 大腿骨を榇取した、大腿骨は無菌状態下で付着性の 軟組織を除去し, PBS 中で洗浄した， その後, 骨端を除 去し、冝バサミで4-6 個の骨片に細断した。細断した骨 片は骨髄細胞を除去するようにPBS中で洗浄し, シャ 一レ内のステンレスステールメッシュによって支持され たレンズペーパー上で, $37^{\circ} \mathrm{C}$ で $\mathrm{CO}_{2} 5 \%$ ，然気 $95 \%$ の気

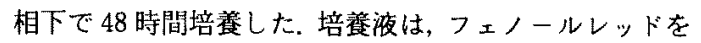
含まないBGJb溶政に $100 \mathrm{IU} / \mathrm{ml}$ の結晶ペニシリン $\mathrm{G}$ カリウム (ベンジルペニシリンカリウム, 明治製菓), $100 \mu \mathrm{g} / \mathrm{ml}$ の硫酸ストレプトマイシン明治（硫酸ストレ プトマイシン, 明治製菓) を添加したものを基本とした。

この培養液に(1) 10\%牛胎子血清 (Gibco), (2) $\mathrm{E}_{2}(1 \times$ $10^{-8} \mathrm{M} / \mathrm{m} l$, Sigma), (3) $\mathrm{T}\left(4.3 \times 10^{-9} \mathrm{M} / \mathrm{m} l\right.$, 半井化学楽 品), (4) $10 \%$ 牛胎子血清および $\mathrm{E}_{2}\left(1 \times 10^{-8} \mathrm{M} / \mathrm{ml}\right)$, (5) $10 \%$ 牛胎子血清书よび $\mathrm{T}\left(4.3 \times 10^{-9} \mathrm{M} / \mathrm{ml}\right) ，(6) 10 \%$ 牛 胎子血清， $\mathrm{E}_{2}\left(1 \times 10^{-8} \mathrm{M} / \mathrm{m} l\right)$ および $\mathrm{T}\left(4.3 \times 10^{-9} \mathrm{M} /\right.$ $\mathrm{ml})$, (7) $\mathrm{E}_{2}\left(1 \times 10^{-8} \mathrm{M} / \mathrm{m} l\right)$ 扩よび $\mathrm{T}\left(4.3 \times 10^{-9} \mathrm{M} / \mathrm{m} l\right)$ をそれぞれ添加して，7種類の培䖯液を使用した． $\mathrm{E}_{2}$ 打 よび Tは, 溶媒としてェタノールを用い，培養液におけ るエタノール最終濃度は $0.1 \%$ になるように調整し $た^{13)}$.

光学颈微鏡による観察のため, 培養前および培養後 48 
時間の骨片は $10 \%$ ホルマリン緩衝液（pH 7.4）で 48 時 間固定した後, $10 \%$ EDTA 溶液 (pH 7.4) で脱灰した. 脱灰後, これらの骨片はアルコール上昇系列にて脱水 し, エンベディウム包埋した. その後, $5 \mu \mathrm{m}$ の切片を作 製し, ヘマトキシリン・エオシン (H-E) 染色もしくは アルシアン青染色を施して観察した.

\section{結果}

培養前の大腿骨骨幹部の骨内膜表面は, 単核で細胞質 に乏しい偏平な骨内膜細胞で広く覆われていたが，一部 には，単核を有する偏平あるいは紡錘形を呈した前骨芽 細胞が観察された (図 1).これらの細胞の上層には, エ オシン陽性の顆粒を含んだ骨能細胞が多数観察された.

これらの大腿骨骨幹部の骨片を 7 種類の培養液で培盖 し, 骨内膜表面に出現した細胞を観察したところ, 培養

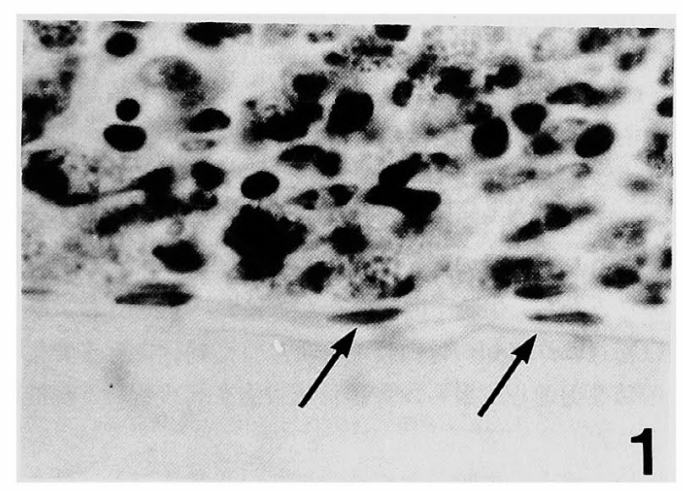

Fig. 1. Flattened-shaped bone lining cells (arrows) are observed on the endosteal bone surface in a quail bone fragment.

$\times 1,000$. Hematoxylin-eosin stain.
液の種類によっては骨内膜細胞および前骨芽細胞のほか に, 単核で立方形を呈した骨芽細胞と, 前骨芽細胞が骨 芽細胞に分化する際に現れる有糸分裂像が認められた。 7 種類の培養液で培養した骨片で，骨内膜表面に出現す るこれらの細胞を 100 個以上計測し,これらの細胞の出 現㓶合を調べたところ，表1に示したとおりであった. すなわち, 対照として用いた培養前の骨片では, 骨内膜 細胞が大多数を占め, 前骨芽細胞の出現はわずかであっ た. 牛胎子血清を含まない培養液に $\mathrm{E}_{2}$ および $\mathrm{T}$ を，そ れぞれ単独添加して培養した骨片において屯骨内膜細胞 が多く観察され, 前骨芽細胞も対照に比べると高い出現 率であった. また, $\mathrm{E}_{2}$ と T を同時に添加して培養した骨 片の骨内膜表面では, これらの性ホルモンを単独添加し たものに比べ骨内膜細胞は少なく, 逆に前骨芽細胞は半 数を超えていた. しかしながら,これらの牛胎子血清を 含まない培養液にいずれのホルモンを添加してあ, 有系 分裂像および骨芽細胞は観察されず, 骨髄骨の存在も認 められなかった。

いっぽう, 牛胎子血清のみを $10 \%$ 添加して培養した 場合には骨内膜細胞が半数以上を占め, 次いで前骨芽細 胞が多数観察された。 また, 有糸分裂像および骨芽細胞 あわずかに認められた。これらの培養液に $\mathrm{E}_{2}$ を添加し た場合には, 前骨芽細胞の出現が最も高く, 次いで骨内 膜細胞, 有糸分裂像および少数の骨芽細胞が観察された (図2).さらに，これら骨芽細胞の骨内膜側には少量の 骨髄骨が認められた、 Tを添加して培養した場合におい ては, $\mathrm{E}_{2}$ 添加培養液の場合と比較して, 骨内膜細胞が多 く観察された. また, 前骨芽細胞, 有系分裂像および骨 芽細胞が認められ，少量の骨䯣骨む観察された。 E 2 お よび T を添加して培養した場合には, 骨内膜細胞が少数 観察され, 骨芽細胞は半数を占めた。 また, 他の培養液

Table 1. Effects of estradiol $\left(\mathrm{E}_{2}\right)$ and testosterone $(\mathrm{T})$ treatments on the cells of the endosteal surface under the presence of the fetal calf serum (FCS) or non-FCS

\begin{tabular}{lcccccc}
\hline \hline Treatments & $\begin{array}{c}\text { Counted cells } \\
\text { (number) }\end{array}$ & $\begin{array}{c}\text { Endosteal cells } \\
(\%)\end{array}$ & $\begin{array}{c}\text { Preosteoblasts } \\
(\%)\end{array}$ & $\begin{array}{c}\text { Mitotic figures } \\
(\%)\end{array}$ & $\begin{array}{c}\text { Osteoblasts } \\
(\%)\end{array}$ & $\begin{array}{c}\text { Medullary } \\
\text { bone* }\end{array}$ \\
\hline Control & 100 & 91.0 & 9.0 & 0 & 0 & - \\
$\mathrm{E}_{2}$ & 130 & 70.0 & 30.0 & 0 & 0 & - \\
$\mathrm{T}$ & 141 & 84.0 & 16.0 & 0 & 0 & - \\
$\mathrm{E}_{2}+\mathrm{T}$ & 132 & 40.9 & 59.1 & 0 & 0 & - \\
$\mathrm{FCS}+\mathrm{E}_{2}$ & 156 & 24.4 & 57.7 & 14.7 & 3.2 & + \\
$\mathrm{FCS}+\mathrm{T}$ & 199 & 46.7 & 41.7 & 10.1 & 1.5 & + \\
$\mathrm{FCS}+\mathrm{E}_{2}+\mathrm{T}$ & 154 & 3.3 & 37.6 & 4.6 & 54.5 & ++ \\
$\mathrm{FCS}$ & 368 & 62.0 & 36.4 & 1.1 & 0.5 & - \\
\hline
\end{tabular}

* Developed degree of the medullary bone : - none, + small, ++ large 


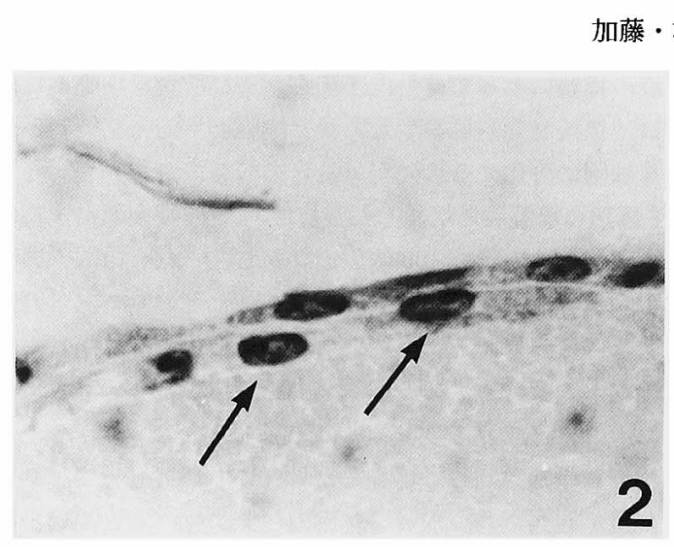

Fig. 2. Flattened- and spindle-shaped preosteoblasts (arrows) are observed on the endosteal bone surface in a quail bone fragment cultured in the fetal calf serum (FCS)-containing medium with $\mathrm{E}_{2}$. $\times 1,000$. Hematoxylin-eosin stain.

のむのと比較して, 骨䯣骨の発達は最む明確に認められ た (図 3).

\section{考 察}

$\mathrm{E}_{2}$ ならびに Tは, マウスの胎子長骨器官培養におい て骨芽細胞に直接作用し，骨形成を促進するということ が報告されている15). しかも，これら性ホルモンによる 骨形成作用は，牛胎子血清を含んだ培養液を用いたとき にのみ観察されることから，牛胎子血清が $\mathrm{E}_{2}$ および $\mathrm{T}$ の骨形成促進作用を惹起することが示唆されている.す なわち，牛胎子血清は，骨形成系細胞の性ホルモンへの 反応を調節するものであると考えられている ${ }^{15)}$. ウズラ 大腿骨の器官培養において, 牛胎子血清を含む培養液に $\mathrm{E}_{2}$ を添加して培養すると, 培養前の骨内膜表面には骨内 膜細胞が多く認められたが, 培養 24 時間後では前骨芽 細胞, 培養 48 時間では骨芽細胞が多くみられ，これらの 骨芽細胞の周囲には骨髄骨が観察されるという ${ }^{12}$. ま た,この骨䯣骨の形成を促す骨形成系細胞にはェストロ ジェンレセプターが存在することが報告されてい $る^{10,11)}$.これらのことから鑑みて，牛胎子血清の存在下 で $\mathrm{E}_{2}$ は骨形成系細胞の分化・増殖に直接的に作用する ことが示唆されている ${ }^{12)}$. 本研究においても, 牛胎子血 清を含む培養液の場合, 骨形成系細胞の分化・增殖が確 認された．牛胎子血清を含む培養液に $\mathrm{E}_{2}$ あるいは $\mathrm{T}$ を 添加して用いた場合, 牛胎子血清を含まない培養液を用 いた場合と比較して, 前骨芽細胞は高い出現率であり, 新たに有糸分裂像および骨芽細胞が観察され，骨髄骨の 形成も認められた. とりわけ，この傾向は， T の添加よ

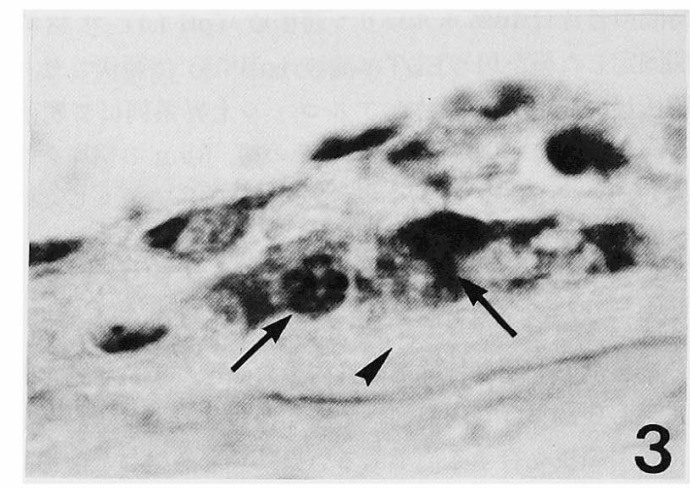

Fig. 3. Cuboidal osteoblasts (arrows) are observed and medullary bone (arrow head) are shown on the endosteal bone surface in a quail bone fragment cultured in FCS-containing medium with both $\mathrm{E}_{2}$ and $\mathrm{T}$.

$\times 1,000$. Alcian blue stain.

りも $\mathrm{E}_{2}$ の添加で強く認められた. $\mathrm{E}_{2}$ および $\mathrm{T}$ の両性ホ ルモンを添加した牛胎子血清を含む培養液を用いた場 合, 大腿骨骨内膜表面にみられる細胞の多くは骨芽細胞 であり, 骨䯣骨の存在が最も明確に認められた。これら のことから, 牛胎子血清の存在下において, $\mathrm{E}_{2}$ および $\mathrm{T}$ は相互に作用し, 骨内膜細胞より骨芽細胞に至る分化・ 增殖を促進し，さらに骨髄骨形成能を高めることが推察 された。

いっぽう, 牛胎子血清を含まない培養液であ, 性ホル モンは骨形成系細胞に作用することが報告されてい る $^{12)}$. 牛胎子血清を含まない培養液に $\mathrm{E}_{2}$ を添加してウ ズラ大腿骨の骨片を培養すると, 骨内膜表面の骨内膜細 胞は前骨芽細胞へ誘導されるという. 本研究において, 牛胎子血清を含まない培養液に $\mathrm{E}_{2}$ を添加して大腿骨骨 幹部の骨片を培養したところ, 培養前と比較して前骨芽 細胞が高い出現率で認められたものの, 骨芽細胞への分 化および骨形成は観察されなかった。. また, 牛胎子血清 を含まない培養液に T のみを添加した場合, 骨内膜細胞 から前骨芽細胞の誘導は認められたが，その後の分化・ 増殖は観察されなかった。 これらのことから本研究で用 いたウズラ大腿骨骨幹部の骨内膜表面において, $\mathrm{E}_{2}$ およ びTがそれぞれ骨内膜細胞に作用して, 前骨芽細胞に誘 導することが確認された。 さらに，牛胎子血清を含まな い培養液に $\mathrm{E}_{2}$ および $\mathrm{T}$ の両方を添加して培養を行なっ た結果, 培養前およびそれらの単独添加培養液を用いた 場合と比較して, より高い前骨芽細胞の出現が認められ た.これらのことから $\mathrm{E}_{2}$ および $\mathrm{T}$ が相互に影響し合っ 
骨䯣骨と性ホルモン

て, 骨内膜細胞から前骨芽細胞への誘尊を強く引き起こ すことが推察された。しかしながら，牛胎子血清を含ま ない培養液に $\mathrm{E}_{2}$ および $\mathrm{T}$ を添加した場合，有系分裂像， 骨芽細胞掞よび骨䯣骨は観察されなかった。これらのこ とから $\mathrm{E}_{2}$ および T だけでは，前骨芽細胞に誘導するす のの，その後の骨芽細胞への分化・增殖および骨骾骨の 粀成には至らないことがうかがえた。

\section{文献}

1) Bloom MA, McLean FC, Bloom W. Calcification and ossification. Anat. Rec., $83: 99-120$. 1942 .

2) Bloom W, Bloom MA, McLean FC. Calcification and ossification. Medullary bone changes in the reproductive cycle of female pigeons. Anat. Rec., 81 : 443-466. 1941.

3) Bowman BM, Miller SC. The proliferation and differentiation of the bone-lining cell in estrogen-induced osteogenesis. Bone, $7: 351$ 357. 1986.

4) Candlish JK. The formation of mineral and organic matrix of fowl cortical and medullary bone during shell calcification. Br. Poult. Sci., 12:119-127. 1971 .

5）楠原征治. Medullary bone の発現に関する研 究. 骨代謝，10：194-197．1977.

6) Kusuhara S, Schraer H. Cytology and autoradiography of estrogen-induced differentiation of avian endosteal cells. Calcif. Tissue Int., $34: 352-358.1982$.

7) Miller SC, Bowman BM. Medullary bone osteogenesis following estrogen administration to mature male Japanese quail. Dev. Biol., 87 : 52-63. 1981.
8）三好昌史，楠原征治．分離・培養したウズラ骨形 成系細胞におよぼすエストロジェンの影響，家离 会誌, $30: 424-429.1993$.

9) Mueller WJ, Schraer R, Schraer H. Calcium metabolism and skeletal dynamics of laying pullets. J. Nutr., 84 : 20-26. 1964.

10) Ohashi T, Kusuhara S, Ishida K. Estrogen target cells during the early stage of medullary bone osteogenesis: Immunohistochemical detection of estrogen receptors in osteogenic cells of estrogen-treated male Japanese quail. Caicif. Tissue Int., $49: 124-127.1991$.

11) Ohashi $T$, Kusuhara $S$, Ishida K. Immunoelectron microscopic demonstration of estrogen receptors in osteogenic cells of Japanese quail. Histochemistry, $96: 41-44.1991$.

12) Ohashi $T$, Kusuhara $S$. Effects of estrogen on the proliferation and differentiation of osteogenic cells during the early stage of medullary bone formation in cultured quail bones. J. Bone Miner. Met., 9 : 253-258. 1991.

13) Pascale $C$, Serre $C M$, Vergnaud $P$, Delmas $\mathrm{PD}$, Meunier PJ. In vitro evaluation of doseeffects of ethanol on human osteoblastic cells. Bone and Mineral, 22 : 95-103. 1993.

14) Schraer $H$, Hunter SJ. The development of madullary bone: A model for asteogenesis. Comp. Biochem. Physiol., 82 A : 13-17. 1985.

15) Schwartz $Z$, Soskolne WA, Neubauer $T$, Goldstein M, Adi S, Ornoy A. Direct and sex-specific enhancement of bone formation and calcification by sex steroids in fetal mice long bone in vitro (Biochemical and morphometric study). Endocrinology, 129: 1167-1174. 1991. 
加藤・杉山・楠原

\title{
Effects of Sex Hormones on Medullary Bone Formation in Cultured Japanese Quail Bones
}

\author{
Kumiko KATO,Toshie SUGIYAMA and Seiji KUSUHARA* \\ Graduate School of Science and Technology. Nigata \\ University, Nigata-shi 950-21 \\ *Faculty of Agriculture, Niigata University, Niigata-shi 950-21
}

The Effects of estradiol $\left(\mathrm{E}_{2}\right)$ and testosterone $(\mathrm{T})$ on the proliferation and differentiation of bone lining cells and medullary bone formation were examined in cultured femurs of adult male Japanese quails. On the endosteal surface of bone fragments cultured in fetal calf serum (FCS)free media with either $E_{2}$ or $T$, far more preosteoblasts were observed in comparison with bone fragments before cultivation. Moreover, a great number of preosteoblasts were seen after cultivation with both $E_{2}$ and $T$, whereas mitotic figures and osteoblasts were not observed and medullary bone formation did not occur after cultivation in FCS-free media. On the other hand, after cultivation in FCS-containing media with either $\mathrm{E}_{2}$ or T, mitotic figures, osteoblasts, and a small amount of medullary bone were observed. The number of osteoblasts and amount of medullary bone were the greatest in the FCS-containing medium with both $E_{2}$ and $T$. These results suggest that $E_{2}$ and $T$ directly stimulate the differentiation of bone lilning cells into preosteoblasts in the absence of FCS. On the other hand, in the presence of FCS, $E_{2}$ and $T$ synergistically stimulate the differentiation and proliferation of the bone lining cells into osteoblasts as well as inducing medullary bone formation.

Anim. Sci. Technol. (Jpn.) 67 (1) : 64-68, 1996

Key words : sex hormone, bone formation, medurally bone, organ culture, Japanese quail 